\title{
Study on Model of Marxist Theory Education In Universities in Internet Background
}

\author{
Weiyu Zhang ${ }^{1, \text { a }}$ \\ ${ }^{1}$ No. 1 Clinical College, Beihua University, Jilin 132013, China. \\ aweiyu_zhang@126.com
}

\begin{abstract}
Keywords: Marxist theory education, Internet features, universities.
\end{abstract}
\begin{abstract}
With the Internet is rapid spread, the Internet thinking have quickly affected the Marxist theory education in universities. Therefore, how to use the Internet model of the basic principles of Marxism education in colleges and universities is the key problem. In this paper, the new model Marxist theory education is proposed to enhance education in basic principles of Marxism. the high-quality Internet of basic principles of Marxism education has been established by reforming and challenging of teaching methods actively based on Internet features.
\end{abstract}

\section{Introduction}

The traditional Marxist theory education is realized through the face-to-face communication between the subject and the object, and it is based on the subject-oriented indoctrination method, and the interaction between the subject and the object is few. The networked Marxist theory education solves this problem, and the educational object can consult the problems faced by the network at any time and anywhere. At the same time, it can discuss and communicate with other objects with the same problems. This not only makes the communication channel between the subject and object unobstructed, but also provides a broader platform for communication between the objects, and at the same time increases the pertinence of education. The rapid popularization of campus network application, so that contemporary college students in the face of domestic and international hot spots, the focus of the problem can be timely and timely response, given their true ideas and views on each other to discuss the exchange of views. Such as WeChat, micro-blog, QQ, Email and other social communication tools for teachers and students online exchange provides a convenient condition. The students' real thoughts and characteristics can be grasped by the teachers in the communication between the teachers and the students, so as to prepare for the next stage of the targeted education. Under the network environment, the Marxist theory education activities, teachers will no longer indulge in indoctrinating knowledge of the machine, but in communication with students to help students understand themselves, the face of self, so the development of self, which is Marxist theory of education Educate people mind. And this also makes the Marxist theory of education is no longer boring monotony, and enhance the Marxist theory of education targeted and timeliness.

Traditional Marxist theory of education authority is reflected in the transmission is one-way, the dissemination of information on the screening, publishing has absolute power, first of the information is true or false, good or bad filtering classification, to its negative bad information The mainstream values and ideology to the recipients of the traditional media such as television, radio, newspapers. The communicators of middle school students are mainly teachers, so that teachers can grasp the controllability of the educational environment, try to avoid students from the impact of the external environment and interference, so that the traditional Marxist theory of education, a more pure public opinion environment . But this authority is being threatened by the network. As a result of various cultural forms, social values and beliefs in the network of mutual integration, the traditional public opinion environment here lost the unity and purity. The main source of information can be obtained through the network, and information publishers are not confined to the government, party organizations and some authoritative institutions and teachers, information dissemination and dissemination of traditional media has gradually been replaced by a wide range of networks. Outside the forest of information through the network by students in a timely manner, so the relatively closed 
traditional public opinion environment will be broken, the impact of teachers on student thinking and control has been greatly weakened. This gives the reactionary forces at home and abroad an opportunity. Western capitalist countries rely on their advantages in network technology, under the banner of democracy and freedom, with the help of the network platform to publicize bourgeois values, outlook on life and belief, Illusion.

\section{The Influence of Network on the Ways and Means of the Education of Marxist Theory}

The traditional teaching mode of Marxist theory is a single structural form centered on the classroom, the teacher as the center and the teaching material as the center. In the classroom, the teacher gives a lot of theoretic explanations on the teaching materials. Although some teaching activities are connected with practical teaching and some teaching effects are obtained, the classroom atmosphere is still boring because the theory is relatively difficult for the college students to comprehend. This kind of education way causes the student to the knowledge theory passive acceptance, thus causes the university student to the Marxism theory the interest to weaken, can not achieve the Marxism theory education ideal effect. Compared to the traditional one-way transmission of information in the traditional teaching model, two-way or even multi-directional information exchange and communication can be achieved through the network of interactivity and immediacy, so that students access to information from more and more, and can choose their own sense of Interest in the content.

Over time, the ability of students to independently judge and choose their own more and more strong, making it difficult for teachers to grasp the complex and diverse ideology of the students. And teachers are still the traditional Marxist theory of education methods and methods of the students blindly "indoctrination" of Marxist theory, the students access to new information through the network will be confused with the content of what teachers say, increasing the difficulty of teaching. Teachers ignore the students' subjective initiative and independence and the nature of the good and evil things to tell the students directly, and asked students to do what not to do, so that the unilateral doctrine will make the Marxist theory of education Attraction is reduced to a great extent. At the same time, the views of individuals can also be open and hidden through the network at random published, which greatly reduces the enthusiasm and participation of students, attention from the classroom to the Internet, and thus lost interest in classroom teaching .

\section{The Influence of Network on the Subject Status of Educators of Marxist Theory}

Nowadays, the important foundation of Marxist theory education lies in the control of information. The main task of the teacher in the process of traditional Marxist theory education is to impart knowledge to the students as the spokesperson of the national social system, and also to accept and acknowledge the students. The control of information is given by the state, and is conducive to teachers to guide students and influence. Teachers in the transfer of knowledge on the subject of the authority of the chain determines the status of knowledge can only be one-way transmission. This teaching model has been deeply rooted for thousands of years, and its effect on the education of Marxist theory is also recognized. China has always been a tradition of teacher worship, so that teachers will be rooted in the authority of each student's heart. In the virtual cyberspace, the exchange of objects into equal individuals, free to express their views, there is no real constraints in the educational environment. Students' independent thinking and self-learning opportunities doubled, making the center of the teacher was shaken. In addition, conservative consciousness makes a large part of today's teachers still do not attach importance to these challenges brought about by the network and did not make the corresponding adjustment of teaching programs, which can not keep up with the trend of teaching environment level of teaching was reduced. In addition, with the popularity of the network, many students in life there will be a considerable part of the time using the computer Internet, through the Internet can easily search a variety of information, and college students to accept new things stronger, even more than a part Due to age, energy and other reasons difficult to reach the 
level of teachers in the network, which to some extent reduce the knowledge gap between teachers and students.

\section{Enrich and innovate the content of Marxist theory education under the network environment}

The Theoretical Core of Marxism in Colleges and Universities Should Be Mastered by College Students. We must make its educational content shallow, popular. Marxist theory of education content to be college students need to be loved by students in the form of display, the abstract content of specific, obscure content vivid. Marxist theory should not be understood only by experts and professors, let the content of Marxist theory education and college students daily learning life, so that students learn to use Marxist theory to analyze life and learning problems, will use the Marx doctrine World outlook and methodology to make correct decisions, from the basic use of Marxist theory to start in the daily life of inspiration, so that students feel the charm of Marxism.

University students can be classified according to grade, pay attention to individuality and differences of college students, design a hierarchical level of educational content, so that different grades of college students to master the different levels of Marxist theoretical knowledge. Most of the Marxist theoretical education focuses on the low-grade college students, while the higher-level students of the Marxist theoretical education is not targeted. Colleges and universities can use the low-grade college students have just entered the campus strong thirst for knowledge and simple values will be the basic content of Marxist theoretical education system to teach them to lay a solid theoretical foundation for college students, cultivate good study habits, establish the right Marxist belief. And for the upcoming graduation of high-grade college students, they already have a relatively mature thinking and forming values, the focus is on their own future development. Therefore, the focus of the content of Marxist theory education in universities should focus on how to combine the theoretical knowledge with practical social problems, to verify the theoretical knowledge through practice, to solve the problems encountered in real life by the theoretical knowledge, The Application of Marxist Theory. It is necessary to break the same level of the Marxist theory of different grades, break the level of Marx's theory of learning in different grades, break the Marxist theory and do not learn a kind of situation, so that students throughout the school life can Marx Interested in educational content.

\section{Build a shared network system}

As the party and the state give Marxist theory education to cultivate the arduous mission of college students with noble character, good quality, lofty ideals and firm belief, the teaching of Marxist theory education has the characteristics of sharing and interactivity. Therefore, colleges and universities should make their own Marxist theory of education and teaching experience and scientific research in time for the exchange and sharing. So as to make the content of Marxist theory education more diversified, so that Marxist theory teaching methods and methods more help students to learn, so that the rapid development of Marxist theory of education to adapt to the current network environment. The construction of an Omni-directional three-dimensional network system of Marxist theory education will be an effective measure to occupy the position of network in the future of Marxist theory education. And the Omni-directional three-dimensional network system is composed of the longitudinal network system and the horizontal network system. First, we construct a vertical network system composed of different levels of Marxist theory education websites. Different levels of macroscopic by the class, grade, school, district, city, province, the final national coverage of the Marxist theory teaching website. So that students can through this vertical Marxist theory of education network channel any level of the site will be quick to browse the latest current affairs and the latest information on the doctrine of Marxist theory to help students better accept the Marx Education of Theoretical Theory. At the same time, the horizontal establishment of a variety of plates, the form closely follow the times, close to the actual contents of the horizontal Marxist theory of education network system. In the past, there are a handful of colleges and universities to establish a 
Marxist theoretical education website, forums, blogs, but the content is complex, material updates are not timely, will not achieve the desired effect. Therefore, colleges and universities can use the current popular micro-Bo, WeChat, QQ and other channels welcomed by college students to disseminate and propagate Marxist theory to college students. If a person to see interest in the theory of Marxist information, in appreciation of it will be forwarded in their own micro-blog WeChat, then there will be more people see, this The butterfly effect makes the Marxist theory spread and develop rapidly. In addition, you can carry out example education, organizing celebrity webinars, celebrities, star effect to attract the attention of college students.

\section{Summary}

Although teachers can communicate with students through social interaction, but because of some of their own conditions and objective reasons will affect the network communication gaps. Colleges and universities need to cultivate a high ideological and political consciousness, with excellent network knowledge and network technology, composite education team to fill this gap. This team should have a strong political quality, a firm belief in Marxism and solid theoretical foundation of Marxist theory. But also with the times, the new knowledge, new theory through the analysis of the order after the reserve into the knowledge of their own knowledge system. So that the team can contact the actual students to recognize, so that Marxist theory to convince students. In addition the team should also have a solid knowledge of communication and network technology. And the quality of education by the team level of network level is very large. The current network to universal access, some college students on the network technology to master the level and level of use can be flush with the educator, even more than educators. This requires educators to study and master the cutting-edge network technology, can use and harness the Marxist theory of education network media, the timely resolution of the network teaching communication problems, so that teaching both vivid and vivid, strong attraction And infectivity. Colleges and universities should rationally manage the configuration of this complex education team, but also continue to strengthen the team's business training, and constantly update the knowledge structure of teachers, and effectively improve the team's professional ethics and professional skills, build a new teaching model , Improve the teaching of relevance and effectiveness. To achieve the full impact of the students and education. In addition, some of the network of Marxist theory of education to carry out better universities can establish demonstration sites for other universities to exchange a good learning experience, the only way to use the network to complete education goals.

\section{References}

[1] WANG Ting. Analysis of the Actual Effect of the Marxist Theory Education of College Students. Journal of Liaoning University of Science and Technology, 2010, 06 (1): 661-664.

[2] YAN Dan-jiang, GUAN Zhi-qiang.Analysis of Marxist Theory Education for College Students under the New Situation.Journal of Jilin Province Education College, 2011, 08, 118-119.

[3] ZHANG Jie, XIAO Ruixian. On Marxist Theory Education of Contemporary College Students Based on the Marxism Chinalization Perspective. Heihe Journal, 2012,06,70-72.

[4] Wang Jing, Tong Shidong. Analysis of the use of the network to carry out the Marxist theory of education. Commercial Culture (Academic Edition), 2010, 11, 11-12.

[5] Zhang Guo. The Spreading of Marxism in Contemporary Chinese College Students. Journal of Shanxi Datong University (Social Science Edition), 2013, 05, 76-78.

[6] Hu Shun.Methods to enhance the practical effect of the Marxist theory education of college students, Party building and ideological education, 2012, 14, 10-11. 